\title{
REDESAIN KOMPOR BRIKET BERBASIS SISTEM KONTROL MENGGUNAKAN KANSEI ENGINEERING
}

\author{
Saufik Luthfianto ${ }^{* 1}$, Siswiyanti ${ }^{2}$, Inayatu Amanah ${ }^{3}$ \\ ${ }^{1,2,3}$ Program Studi Teknik Industri Universitas Pancasakti Tegal \\ Jl. Halmahera Km. 1 Kota Tegal, 52121 \\ Email: saufik.ti.upstegal@gmail.com, siswieyanti@gmail.com, \\ inayatuamanah39@gmail.com
}

(artikel diterima: 04-04-2020, artikel disetujui: 06-07-2020)

\begin{abstract}
Abstrak
Kompor briket dirancang menggunakan Kansei Engineering diawali dengan wawancara kepada responden untuk menghasilkan interpretasi kebutuhan, dari interpretasi kebutuhan dirangkum menjadi beberapa kata kansei yang relevan terhadap perancangan kompor briket, tahap berikutnya diuji dengan uji kuesioner pertama dan dilanjutkan dengan kuesioner 2 tentang spesifikasi kompor. Tujuan dari penelitian ini adalah meredesain kompor briket berbasis sistem kontrol dan meningkatkan daya elastisitas kain dan rekat malam menggunakan kensei engineering. Hasil redesain kompor briket berbasis sistem kontrol menggunakan Kansei Engineering adalah kompor briket portable menggunakan sensor suhu berbasis arduino dan uji daya rekat meghasilkan tingkat daya rekat malam batik naik sebesar $33,3 \%$ sedangkan untuk uji elastisitas malam batik yang dipanaskan dengan kompor baru menghasilkan tingkat keretakan lebih kecil yaitu naik sebanyak $100 \%$.
\end{abstract}

Kata kunci: Arduino, Batik, Kansei Enginneering, Kompor

\begin{abstract}
Briquette stove is designed using the Kansei Engineering method. Beginning with interviews with respondents to produce interpretations of needs, then the interpretation of needs is summarized into several words kansei that are relevant to the design of briquette stoves, the next step is tested with the first questionnaire test after that followed by questionnaire 2 about the specifications of the stove. The purpose of this research is to design a control system based briquette stove and increase the elasticity of the fabric and the adhesive at night using engineering kensei. The results of the redesign of the briquette stove based on the control system using Kansei Engineering are portable briquette stoves using an arduinobased temperature sensor and the adhesive power test results in a batik night adhesion level rising by 33.3\% while for the elasticity test the batik night that is heated with a new stove produces more cracks small is up by $100 \%$.
\end{abstract}

Keywords: Arduino, Batik, Kansei Engineering, Stove

\section{PENDAHULUAN}

Kompor merupakan alat yang menghasilkan kalor dengan desain ruang pembakaran tertutup dan digunakan sebagai tempat memanaskan barang di atasnya (Subiantoro and Wiwi, 2015). Salah satu kompor yang sampai sekarang masih digunakan oleh para pembatik Arum Cempaka di desa Jebed adalah kompor minyak tanah karena penggunaanya yang mudah. Namun, kelangkaan minyak tanah menjadi masalah baru bagi pembatik. Hal ini membuat pembatik perlu mulai beralih ke bahan bakar alternatif. Bahan bakar alternatif yang terbuat dari produk alam dan mudah didapat adalah briket. Briket merupakan salah satu energi alternatif terbarukan yang 
potensinya besar di Indonesia (Arga Setia Tama, 2012). Di dalam survey pendahuluan ditemukan permasalahan yaitu kompor briket dipasaran mempunyai beberapa kekurangan seperti, bahan kompor yang mudah korosi, tempat pembuangan abu yang kurang mudah dalam membersihkannya, tempat pembakaran briket yang menyatu dengan kerangka utama kompor sehingga mengakibatkan kerangka utama kompor ikut cepat rusak, kompor briket juga tidak ada indikator khusus yang menunjukan bahwa briket didalam kompor masih menyala atau sudah habis. Beberapa penelitian menunjukkan perbaikan dalam perancangan kompor diantaranya menurut (Wijana and Nurchayati, 2013) tungku berbahan baku briket hasil rancangannya menghasilkan peningkatan lama pemakaian nyala api sebesar 300\% untuk sekali pengisian, dari penelitian tersebut performansi kompor dapat diukur dan menurut (Anam et al., 2017) meningkatkan performa kompor yang berbeda desain diukur dengan empat performansi dan perbedaan ketinggian ruang bakar, menghasilkan performansi yang optimal dengan membandingkan ketinggian ruang bakar, tetapi performansi optimal dirasa kurang efektif ketika suhu tidak dikontrol, menurut (Maulana, 2018) menggunakan suhu tertinggi dan terendah untuk menghasilkan malam batik menggunakan kompor listrik yang dirancang dengan sistem kontrol suhu, sehingga bahan malam dapat dikontrol secara efektif. Tidak hanya sistem kontrol tetapi sistem pengaturan udara juga dikontrol seperti pada pnelitian (Kurniawan and Sasongko, 2018) merancang tungku biomassa yang memiliki sistem pengaturan udara pembakaran dan sistem pengeringan kayu bakar metode yang digunakan adalah perancangan dan fabrikasi dan pengujian pada karakteristik pembakaran dan unjuk kerja sehingga laju perpindahan panas energi yang dihasilkan pada briket dapat disalurkan, menurut (Faisal and Mahyuddin, 2019) dengan menggunakan metode eksperimen besarnya laju perpindahan panas yang terjadi pada bagian dinding kompor yang tak terisolasi sebagai akibat dari proses pengkonversian energi bio briket menjadi energi termal dan menghasilkan besarnya laju perpindahan panas pada dinding kompor bio briket yang tak terisolasi sangat berpengaruh pada unjuk kerja kompor bio briket. Melihat kekurangan-kekurangan tersebut, maka diperlukan perancangan kompor briket yang lebih baik lagi. Ketika akan merancang suatu produk diperlukan psikologi konsumen yang positif sehingga menjadi bahan pertimbangan peneliti. Konsumen memilih produk yang mempunyai kesan positif pada produk tersebut. Oleh karena itu, perlu dilakukan penelusuran terhadap emosi dan perasaan yang ingin dirasakan oleh pengguna terhadap suatu produk, yang pada akhirnya akan diimpelentasikan ke dalam suatu rancangan konsep produk (Wahyuning, Desrianty and Rahmawati, 2011). Menurut (Mastur and Hadi, 2005) bahwa perancangan menggunakan kansei engineering dapat digunakan untuk merancang berbagai macam produk terutama dalam mengidentifikasi pola desain produk, sehingga menurut (Puspitasari, Sugiharto and Anizar, 2014) menggunakan kansei engineering untuk merancang kompor dan alternatif berbahan bakar alternatif tersebut mampu manambah nilai ekonomis dan meminimalisir biaya produksi dan menterjemahkan psikologis konsumen dengan kensei words adalah metode yang digunakan (Rahmayani, Yuniar and Desrianty, 2015) (Nugroho et al., 2017). Dari beberapa penelitian diatas bahwa penggunaan kontrol udara dan briket sebagai bahan bakar kompor maka peneliti menyimpulkan bahwa pada perancangan kompor ini dirancang menggunakan kansei engineering untuk menterjemahkan psikologis konsumen dengan kensei word untuk meredesain kompor yang menggunakan sistem kontrol. 


\section{METODE PENELITIAN}

\subsection{Metode}

Penelitian ini menggunakan metode rancangan dengan kansei engineering dan eksperimental untuk menguji daya rekat dan daya elastisitas malam batik pada kompor konvensional dan kompor rancangan. Menurut (Sugiyono, 2017) penggunaan data kuantitatif karena data dan penelitian merupakan olah data yang berasal dari survey.

\subsection{Bahan}

Bahan yang dibutuhkan untuk redesain kompor briket ini adalah sensor suhu (ntc), software arduino dengan bahasa pemograman C, kabel jamper, baterai, malam dan kain putih berukuran $1 \mathrm{~m}$ x $1 \mathrm{~m}$.

\subsection{Proses rancangan dengan kansei engineering}

Pada proses pertama adalah mengumpulkan kata kansei yang berkaitan dengan produk kompor kepada konsumen kemudian kata kensei dievaluasi melalui metode Semantic Deffential I yang terdiri dari tes kecukupan data, pengelompkan kensei word dengan analisis faktor, tahap berikutnya adalah pemilihan spesifikasi desain kompor dan pembuatan kompor.

\subsection{Proses eksperiment}

Pada proses eksperiment pertama adalah dengan pembuatan kompor dengan sistem kontrol suhu kemudian dilakukan pemograman arduino menggunakan bahasa pemograman $\mathrm{C}$ sehingga dalam pemograman tersebut dilihat terlebih dahulu pada suhu berapa briket mulai habis dan pada suhu berapa malam akan meleleh sempurna. Hasil malam pada kompor briket berbasis sistem kontrol arduino diterapkan pada kain kemudian kain tersebut dilakukan pengujian laboratorium untuk mengetahui daya rekat malam dan uji elastisitas malam atau daya retak malam.

Gambaran secara sistematis dapat dilihat pada diagram alir penelitian dibawah ini:

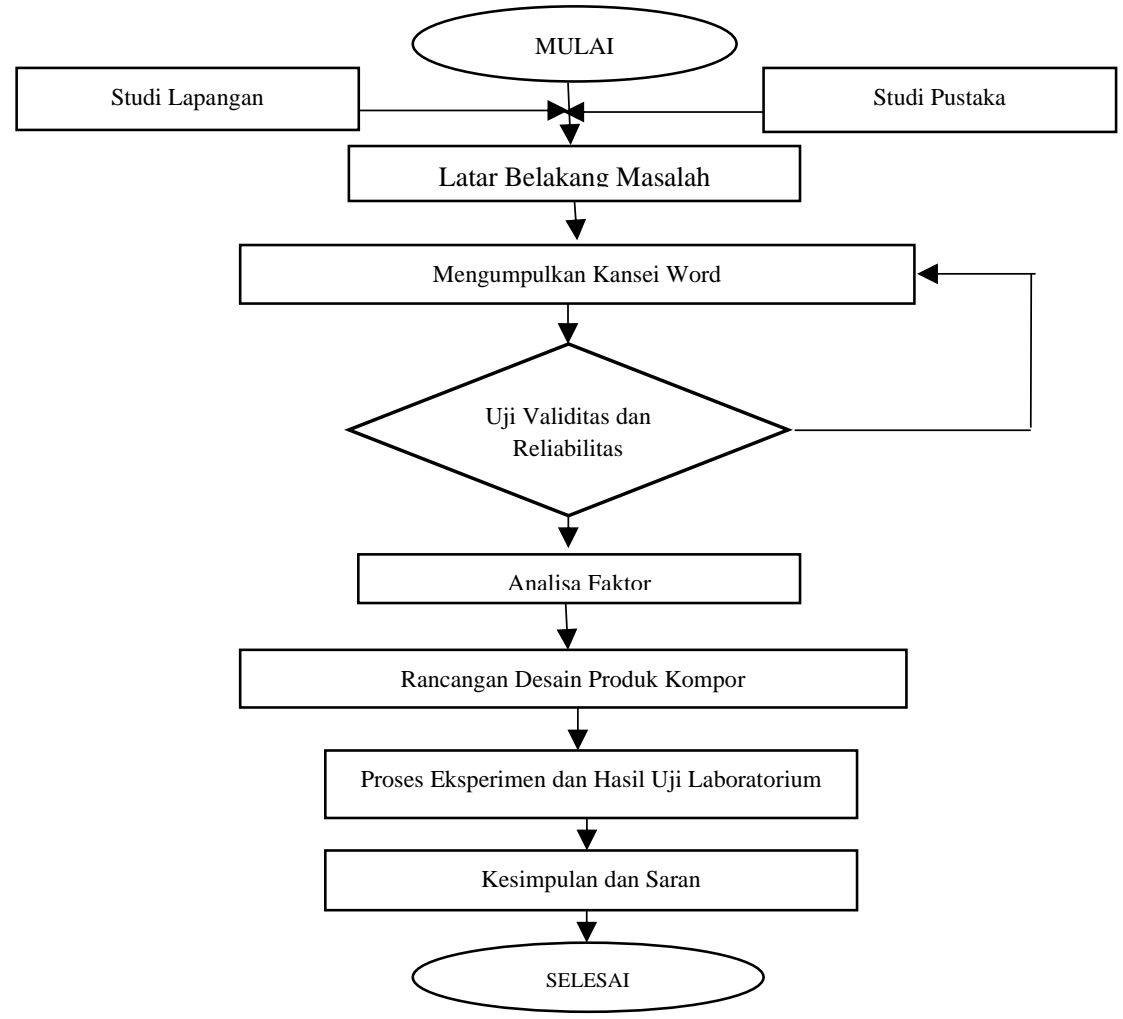

Gambar 1. Diagram alir penelitian 


\section{HASIL DAN PEMBAHASAN}

\subsection{Hasil}

\subsubsection{Kansei word}

Tabel 1. Kansei Word Perancangan Kompor Briket

\begin{tabular}{cc}
\hline No & Kensei Word \\
\hline 1 & Desain \\
2 & Bahan Kompor \\
3 & Tempat Briket \\
4 & Tempat Abu \\
5 & Sensor Suhu \\
\hline & Sumber: hasil kuesioner, 2019
\end{tabular}

Dari tabel 1 diatas langkah pertama adalah mengumpulkan data identifikasi dari pelanggan yaitu mengumpulkan data melalui wawancara terbuka terhadap responden (sentra industri batik tulis arum cempaka). Dari hasil wawancara terbuka dihasilkan lima kansei word utama yang relevan terdapat perancangan kompor briket yang diperoleh dari identifikasi kebutuhan terhadap pembatik yaitu mudah digunakan berhubungan dengan desain dimana mudah digunakan juga berhubungan langsung dengan tempat briket dan tempat abu pembuangan, awet berhubungan dengan bahan atau amtrial kompor, indikator briket berhubungan dengan sensor suhu.

\subsubsection{Uji Validitas}

Tabel 2. Output Uji Validitas

\begin{tabular}{clcc}
\hline No & \multicolumn{1}{c}{ Atribut } & r hitung & r tabel \\
\hline 1 & Desain Kompor &, 470 &, 39 \\
2 & Bahan Kompor &, 486 &, 39 \\
3 & Tempat Briket &, 744 &, 39 \\
4 & Tempat Abu &, 574 &, 39 \\
5 & Sensor Suhu &, 744 &, 39 \\
\hline Sumber: Output SPSS, 2019 & &
\end{tabular}

Dari tabel 2 diatas terlihat bahwa nilai $\mathrm{N}=23$ berdasarkan tabel $\mathrm{r}$ menghasilkan $\mathrm{r}$ tabel sebesar 0,39 sehingga semua item diatas adalah valid.

\subsubsection{Uji Reliabilitas}

\begin{tabular}{cc}
\multicolumn{2}{c}{ Tabel 3. Uji Reliabilitas } \\
\hline r hitung & r tabel \\
\hline \multirow{2}{*}{, 811} &, 39 \\
\hline
\end{tabular}

Dari tabel 3 diatas bahwa nilai $\mathrm{r}$ hitung sebesar $0,811>\mathrm{t}$ tabel sebesar 0,39, maka dapat dinyatakan bahwa kuesioner adalah reliabel.

\subsubsection{Uji KMO And Barlett's}

Tabel 4. Uji KMO And Bartlett's

\begin{tabular}{cc}
\hline Nilai hitung &, 660 \\
\hline $\mathbf{p}$ &, 008 \\
\hline
\end{tabular}


Dari tabel 4 diatas diketahui nilai KMO MSA sebesar 0,660 > 0,50 maka teknik analisis faktor dapat dilanjutkan karena sudah memenuhi persyaratan lebih besar dari 0,05

\subsubsection{Pengujian Anti Image Matrices}

Tabel 5. Anti Image Matrics

\begin{tabular}{llccccc}
\hline & & $\begin{array}{c}\text { Desain } \\
\text { Kompor }\end{array}$ & $\begin{array}{c}\text { Bahan } \\
\text { Kompor }\end{array}$ & $\begin{array}{c}\text { Tempa } \\
\text { t Briket }\end{array}$ & $\begin{array}{c}\text { Tempa } \\
\text { t Abu }\end{array}$ & $\begin{array}{c}\text { Sensor } \\
\text { Suhu }\end{array}$ \\
\hline Anti-Image & Desain Kompor &, $669^{\mathrm{a}}$ &,- 446 &,- 288 &,- 138 &,- 071 \\
Correlation & Bahan Kompor &,- 446 &, $715^{\mathrm{a}}$ &,- 070 &,- 126 &,- 111 \\
& Tempat Briket &,- 288 &,- 070 &, $586^{\mathrm{a}}$ &, 178 &,- 060 \\
& Tempat Abu &,- 138 &,- 126 &, 178 &, $624^{\mathrm{a}}$ &,- 507 \\
& Sensor Suhu &,- 071 &,- 111 &,- 060 &,- 507 &, $661^{\mathrm{a}}$ \\
\hline
\end{tabular}

Dari tabel 5 diatas nilai MSA dari Desain Kompor 0,669, Bahan Kompor 0,715, Tempat Briket 0,586, Tempat Abu 0,624 dan Sensor Suhu sebesar 0,661

\subsubsection{Output Communities}

Tabel 6. Communities

\begin{tabular}{lcc}
\hline Atribut & Initial & Extraction \\
\hline Desain Kompor & 1,000 &, 700 \\
Bahan Kompor & 1,000 &, 612 \\
Tempat Briket & 1,000 &, 703 \\
Tempat Abu & 1,000 &, 768 \\
Sensor Suhu & 1,000 &, 687 \\
\hline
\end{tabular}

Extraction Method: Principal Component Analysis.

\subsubsection{Proses Factoring}

Tabel 7. Proses faktoring

\begin{tabular}{cccc}
\hline \multirow{2}{*}{ Komponen } & \multicolumn{3}{c}{ Faktor yang terbentuk } \\
\cline { 2 - 4 } & Total & Variansi (\%) & Kumulatif (\%) \\
\hline 1 & 2,284 & 45,687 & 45,687 \\
2 & 1,185 & 23,709 & 69,396 \\
3 &, 690 & 13,795 & 83,191 \\
4 &, 438 & 8,765 & 91,956 \\
5 &, 402 & 8,044 & 100,000 \\
\hline
\end{tabular}

Tabel 6 dan 7 menunjukkan komponen yang dianalisis pada faktor yang terbentuk yaitu dengan nilai total 5 dari penjumlahan nilai total masing-masing komponen yaitu $2,284+1,185+0,690+0,438+0,402$ 
3.1.8. Output matrik komponen

Tabel 8. Matrik Komponen

\begin{tabular}{lcc}
\hline \multirow{2}{*}{ Atribut } & \multicolumn{2}{c}{ Komponen } \\
\cline { 2 - 3 } & r Faktor 1 & r Faktor 2 \\
\hline Desain Kompor &, 766 &, 336 \\
Bahan Kompor &, 760 &, 186 \\
Tempat Briket &, 362 &, 756 \\
Tempat Abu &, 692 &,- 539 \\
Sensor Suhu &, 715 &,- 420 \\
\hline
\end{tabular}

Pada tabel 8 menunjukkan matrik komponen nilai korelasi antara masing-masing variabel dengan faktor yang terbentuk. Pada variabel Desain Kompor, yakni nilai korelasi variabel ini dengan faktor 1 adalah 0,766, dan korelasi dengan faktor 2 sebesar 0,336. Untuk variabel Bahan Kompor yakni nilai korelasi variabel ini dengan faktor $1=0,760$, dan korelasi dengan faktor $2=0,186$. Untuk variabel Tempat Briket yakni nilai korelasi variabel ini dengan faktor $1=0,362$, dan korelasi dengan faktor $2=0,754$. Untuk variabel Tempat Abu yakni nilai korelasi variabel ini dengan faktor $1=0,692$, dan korelasi dengan faktor $2=0,539$. Untuk variabel Sensor Suhu yakni nilai korelasi variabel ini dengan faktor $1=0,715$, dan korelasi dengan faktor $2=0,420$

\subsubsection{Output Matrik Komponen yang diputar}

Tabel 9. Matrik Komponen yang diputar

\begin{tabular}{lcc}
\hline \multirow{2}{*}{ Atribut } & \multicolumn{2}{c}{ Komponen } \\
\cline { 2 - 3 } & r Faktor 1 & r Faktor 2 \\
\hline Desain Kompor &, 367 &, 752 \\
Bahan Kompor &, 459 &, 633 \\
Tempat Briket &,- 213 &, 811 \\
Tempat Abu &, 876 &, 036 \\
Sensor Suhu &, 817 &, 142 \\
\hline
\end{tabular}

Tabel 9 menunjukkan suatu variabel masuk dalam kelompok faktor mana, dapat ditentukan dengan melihat nilai korelasi terbesar antara variabel dengan faktor komponen yang terbentuk. Hasil dari tabel 9 dapat dilihat pada tabel 10 pengelompokkan masing-masing variabel.

Tabel 10. Pengelompokan Untuk Masing-Masing Kategori

\begin{tabular}{cc} 
Kelompok Faktor $\mathbf{1}$ & Kelompok Faktor 2 \\
\hline Tempat Abu & Desain Kompor \\
Sensor Suhu & Tempat Briket \\
& Bahan Kompor \\
\hline
\end{tabular}




\subsubsection{Output Matrik Transformasi}

Tabel 11. Matrik Transformasi

\begin{tabular}{ccc}
\hline Komponen & r hitung 1 & r hitung 2 \\
\hline 1 &, 763 &, 647 \\
2 &,- 647 &, 763 \\
\hline
\end{tabular}

Pada tabel 11 yaitu matrik transformasi menunjukkan nilai korelasi semua komponen $>$ 0,5 maka kedua faktor dapat merangkum kelima variabel yang.

\subsubsection{Evaluasi Kuesioner Tahap 2}

Pada tahap ini dilakukan penilaian responden terhadap spesifikasi desain yang telah ditentukan oleh penulis berdasarkan interpretasi kebutuhan bersarakan hasil pertanyaan dan pernyataan pada wawancara terhadap responden dan responden memberikan nilai sesuai dengan keinginannya dari skor 1-5 dengan keterangan sebagai berikut: 1: menunjukan perasaan responden yang sangat tidak suka terhadap desain tersebut. 2: menunjukan perasaan responden yang tidak suka terhadap desain tersebut. 3: menunjukan perasaan responden yang netral terhadap desain tersebut, 4: menunjukan perasaan responden yang suka terhadap desain tersebut, 5: menunjukan perasaan responden yang sangat suka terhadap desain tersebut. Rekapitulasi hasil kuesioner dapat dlilihat pada tabel 12 dibawah ini:

Tabel 12. Score Pemilihan Spesifikasi Kompor

\begin{tabular}{lll}
\hline & Score Rata-Rata & \\
\hline Desain Kompor & $40 * 30$ & 3,92 \\
& $30 * 30$ & 4,00 \\
Bahan Kompor & Galvanum anti karat & 3,62 \\
& Seng biasa yang dicat & 3,50 \\
Tempat Briket & Model sarang ayakan pasir & 3,96 \\
& Model sarang panci & 3,69 \\
Tempat Abu & Kotak dengan sisi penuh & 3,73 \\
& Kotak dengan ujung tak bersisi & 3,54 \\
Sensor Suhu & DHT11 & 3,77 \\
& NTC & 3,81 \\
\hline
\end{tabular}

Dari hasil score pemilihan spesifikasi kompor maka untuk tahapan 1 mengimplementasikannya adalah dengan merancang desain kompor briket tersebut 


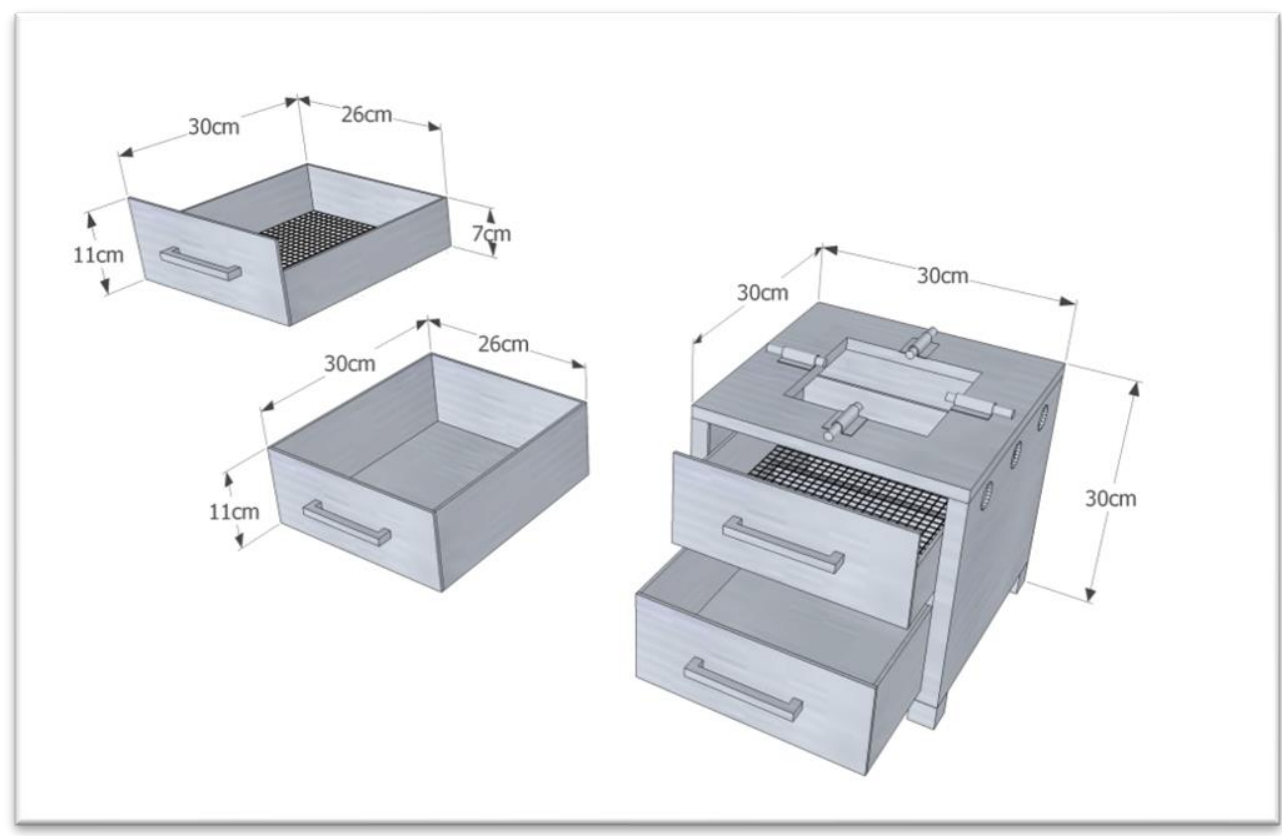

Gambar 2. Rancang desain kompor briket berbasis sistem kontrol

\subsubsection{Tahap Pembuatan Kompor}

Berikut adalah peta proses operasi pembuatan kompor: 


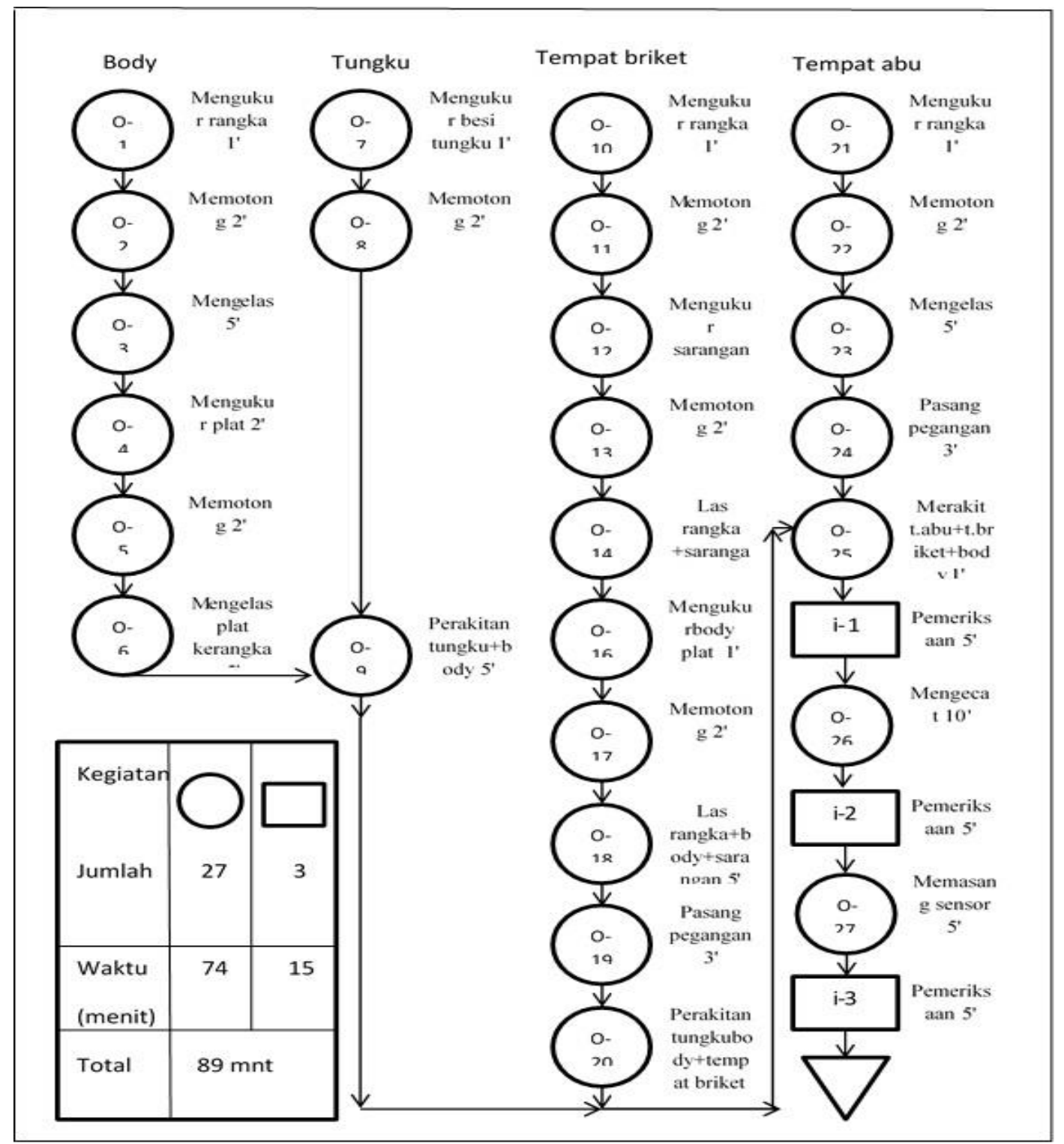

Gambar 3. Peta Proses Operasi Pembuatan kompor briket berbasis sistem kontrol

Berdasarkan gambar 3 peta proses operasi pembuatan kompor briket portable adalah diawali dengan pembuatan body kompor, diawali dengan proses mengukur untuk bagian rangka kompor dilakukan sekitar 1 menit, memotong rangka yang telah diukur menggunakan alat khusus pemotong galvanum dilakukan selama 2 menit, dilanjutkan dengan proses pengelasan dilakukan sekitar 5 menit, kemudian melakukan pengukuran plat selama 2 menit, memtong plat dengan alat khusus selama 2 menit, dilanjutkan dengan proses pengelasan plat dan kerangka selama 5 menit. Proses pembuatan tungku diawali dengan mengukur brsi tungku dilakukan selama 1 menit dan memotong selama 2 menit, dilanjutkan proses perakitan tungku dan body yang sudah dilas selama 5 menit. Selanjutnya adalah pembuatan tempat briket, diawali dengan proses mengukur selama 1 menit, memotong selama 1 menit, kemudian mengukur sarangan selama 1 menit, memotong sarangan yang telah diukur selama 2 menit, mengelas rangka dan sarangan selama 5 menit, dilanjutkan dengan mengukur body plat selama 1 menit, memotong body plat selama 2 menit, dilanjutkan dengan 
mengelas rangka dan body serta sarangan selama 5 menit, memasang pegangan sarangan selama 3 menit, perakitan tungku body dan tempat briket. Selanjutnya dalah proses pembuatan tempat abu, dilakukan dengan mengukur rangka selama 1 menit, memotong rangka yang telah diukur selama 2 menit, mengelas antar rangka selama 5 menit, memasang pegangan dilakukan selama 3 menit, dilanjutkan dengan merakit tempat abu, tempat briket, dan body selama 1 menit. Proses selanjutnya adalah pemeriksaan keseluruhan komponen selama 1 menit, dilanjutkan dengan proses pengecetan selama 10 menit, dilakukan pemeriksaan kembali selama 1 menit, pemasangan sensor yang sudah jadi ke body kompor selama 5 menit, dilanjutkan dengan pemeriksaan kembali apakah sensor sudah terpasang dengan benar dilakukan selama 1 menit selanjutnya proses dikatakan telah selesai sperti terlihat pada gambar 4 dibawah ini.

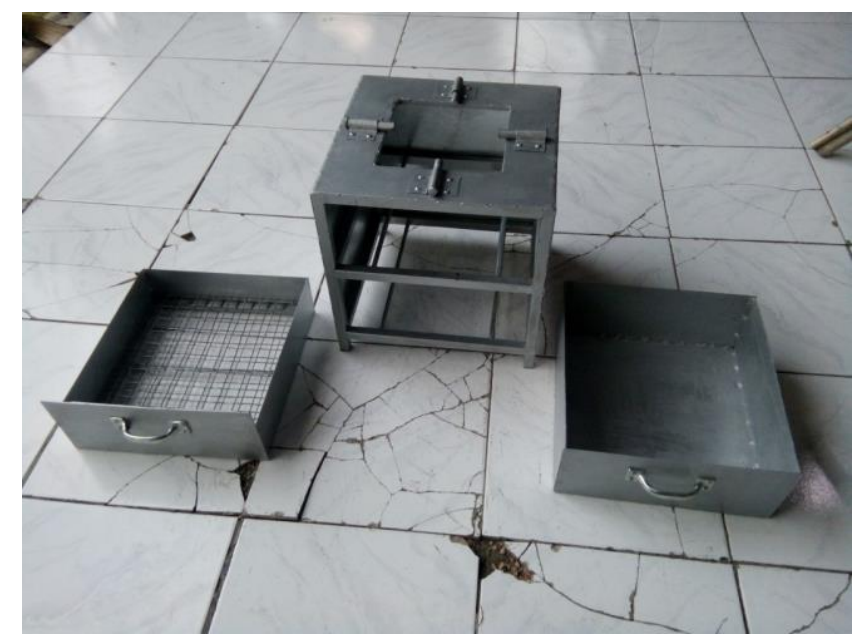

Gambar 4. Rancang bangun kompor briket berbasis sistem kontrol

\subsubsection{Rancangan Sensor Suhu Berbasis Arduino}

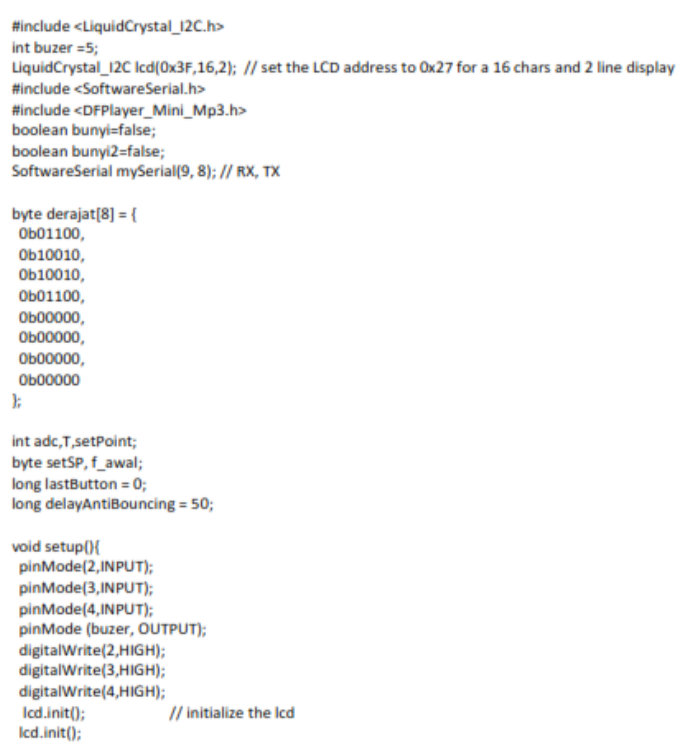


TEKINFO - Jurnal IImiah Teknik Industri dan Informasi

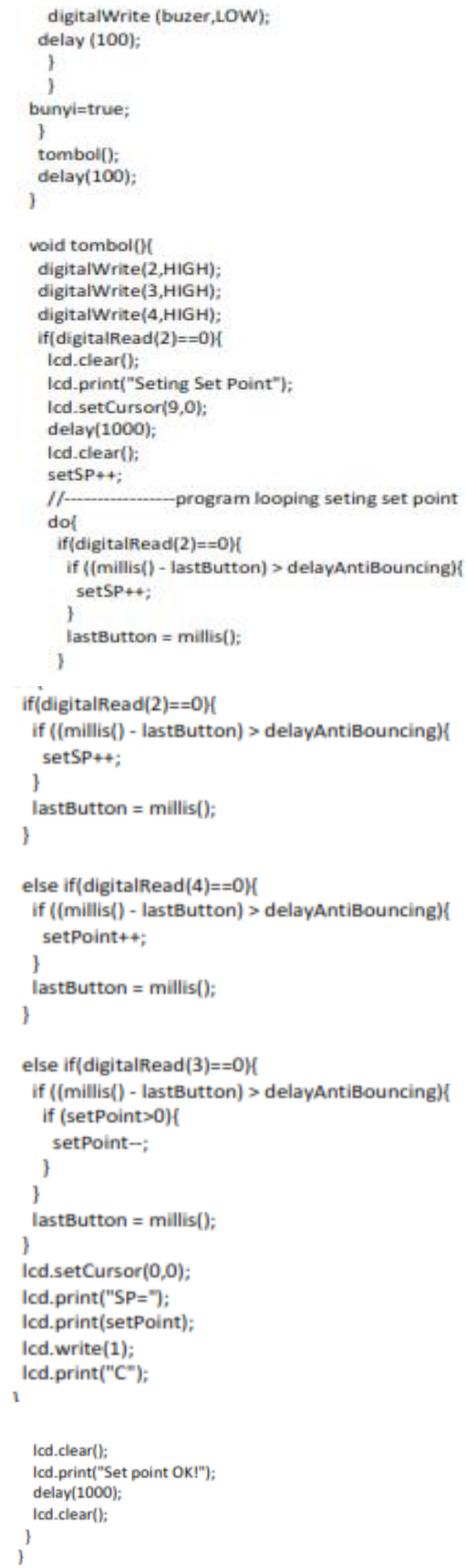

Gambar 5. Bahasa Pemograman Arduino Pada Kompor Briket 


\subsubsection{Hasil Uji Laboratorium Daya Rekat dan Daya Elastisitas Malam Batik Setelah Dilakukan Perancangan Kompor Briket Portable.}

Hasil uji lab pada malam dan kain batik dapat digambarkan pada gambar 6 dibawah ini:

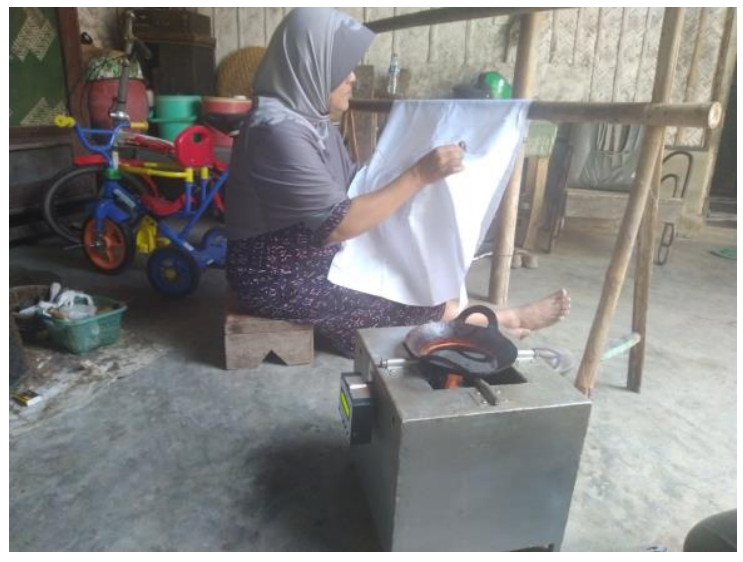

Gambar 6. Uji coba laboratorium pada kompor briket berbasis sistem kontrol

Hasil pengujian kompor menghasilkan hasil uji daya tembus malam pada kain dan uji elastisitas malam batik, sehingga menghasilkan perbandingan antara kompor lama dengan kompor baru yaitu berbasis sistem kontrol

Tabel 13. Hasil Uji Laboratoruim Daya Tembus Malam Batik Pada Kain Dan Pengujian Elastisitas Malam Batik

\begin{tabular}{ccc}
\hline Jenis Sampel & $\begin{array}{c}\text { Hasil Uji Daya Tembus Malam } \\
\text { Batik Pada Kain }\end{array}$ & $\begin{array}{c}\text { Hasil Uji Elastisitas } \\
\text { Malam Batik }\end{array}$ \\
\hline Kompor Lama & $40 \%$ & $40 \%$ \\
Kompor Baru & $65 \%$ & $20 \%$ \\
\hline
\end{tabular}

Tabel 13 merupakan hasil uji laboratorium pada daya tembus malam pada kain dan elastisitas malam, pada jenis sampel kompor lama menghasilkan $60 \%$ dan kompor baru $65 \%$ pada uji daya tembus malam sedangkan uji elastisitas pada kompor lama $40 \%$ dan kompor baru $20 \%$.

\subsection{Pembahasan}

Pengujian daya tembus malam batik pada kain mempunyai kriteria sebagai berikut:Sangat Baik, Jika $>80 \%$ malam tembus pada kain. Baik, Jika $>61 \%-80 \%$ malam tembus pada kain.Cukup, Jika $>41 \%-60 \%$ malam tembus pada kain.Kurang, Jika $>20 \%-40 \%$ malam tembus pada kain. Sangat Kurang, Jika $<20 \%$ malam tembus pada kain. Uji Elastisitas Malam Batik. Pengujian elastisitas malam batik mempunyai kriteria sebagai berikut: Sangat Baik, Jika $<20 \%$ malam yang melekat pada kain mengalami keretakan. Baik, Jika $20 \%-40 \%$ malam yang melekat pada kain mengalami keretakan. Cukup, Jika $41 \%-60 \%$ malam yang melekat pada kain mengalami keretakan. Kurang, Jika $61 \%-80 \%$ malam yang melekat pada kain mengalami keretakan. Sangat Kurang, Jika $>80 \%$ malam yang melekat pada kain mengalami keretakan. 
Hasil uji laboratorium yang telah dilakukan di Laboratorium Teknologi Batik Pekalongan yaitu pengujian daya tembus malam batik pada kain dan pengujian elastisitas malam batik. Dari tabel 13 Hasil Uji Laboratorium Daya Tembus Malam Batik Pada Kain dan Pengujian Ekastisitas Malam Batik, dapat diartikan bahwa kualitas malam yang dipanaskan menggunakan kompor lama pada uji daya tembus malam batik terhadap kain mengasilkan hasil uji laboratorium sebesar $45 \%$, sedangkan kualitas malam yang dipanaskan menggunakan kompor baru pada uji daya tembus malam batik terhadap kain mengasilkan hasil uji laboratorium sebesar $60 \%$. Sedangkan pada uji elastisitas malam batik yaitu menjelaskan tentang pada tingkat berapa persen malam mengalami keretakan. Semakin rendah retaknya maka kualitas malam makin baik. Pada hasil uji daya elastisitas malam batik yang dilakukan menghasilkan angka daya retak sebesar $40 \%$ pada malam batik yang dipanaskan dengan kompor lama sedangkan malam yang dipanaskan dengan kompor baru menghasilkan tingkat keretakan yang lebih rendah yaitu sebesar 20\%. Berdasarkan Tabel 13 dapat dihitung berdasarkan hasil persentasinya adalah sebagai berikut:

Uji daya rekat malam terhadap kain: $=\frac{60 \%-45 \%}{45 \%} x 100=33,3 \%$,

Uji daya elastisitas atau daya retak malam $=\frac{40 \%-20 \%}{20 \%} \times 100=100 \%$

Dari hasil perhitungan persentasi uji daya rekat dan elastisitas malam dapat diambil kesimpulan bahwa malam yang dipanaskan kompor baru meghasilkan tingkat daya rekat malam batik naik sebesar 33,3\% sedangkan untuk uji elastisitas malam batik yang dipanaskan dengan kompor baru menghasilkan tingkan keretakan lebih kecil yaitu naik sebanyak $100 \%$.

\section{KESIMPULAN}

1. Hasil kansei engineering yaitu menggunakan analisa faktor nilai korelasi semua komponen > 0,5 maka kedua faktor yang terbentuk ini dapat disimpulkan layak untuk merangkum kelima variabel yang dianalisis yaitu spesifikasi kompor briket yang dihasilkan adalah kompor briket portable dengan sensor suhu berbasis arduino dengan nilai score rata-rata 3,77 dan 3,81.

2. Hasil perhitungan persentasi uji daya rekat dan elastisitas malam menghasilkan tingkat daya rekat malam batik naik sebesar 33,3\% sedangkan untuk uji elastisitas malam batik yang dipanaskan dengan kompor baru menghasilkan tingkat keretakan lebih kecil yaitu naik sebanyak $100 \%$.

\section{DAFTAR PUSTAKA}

Anam, A. et al. (2017) 'Pengaruh Dimensi Kompor Biomasa Terhadap Performansinya', Journal of Technical Engineering:Piston, 1(1), pp. 19-24.

Arga Setia Tama (2012) 'Perancangan kompor briket biomass untuk limbah kopi', Jurnal Teknik POMITS, 1(1), pp. 1-6.

Faisal, M. and Mahyuddin (2019) 'Kaji Eksperimental Kehilangan Panas Pada Dinding Kompor Biobriket Tak Terisolasi', Jurnal Ristech (Jurnal riset, Sains dan Teknologi), 1(1), pp. 8-20. 
Kurniawan, S. D. and Sasongko, B. T. (2018) 'Design of Green Energy Stove: Characteristics of Combustion and Performance', in Conference SENATIK STT Adisutjipto Yogyakarta. doi: 10.28989/senatik.v4i0.218.

Mastur, I. and Hadi, L. (2005) 'Implementasi Jaringan Syaraf Tiruan Untuk Mengidentifikasi Pola Desain Produk Berdasarkan Preferensi Pelanggan Menggunakan Kansei Engineering System', Teknoin, 10(3), pp. 197-208. doi: 10.20885/teknoin.vol10.iss3.art3.

Maulana, M. Y. (2018) Rancang Bangun Sistem Kontrol Suhu Kompor Batik Listrik Dengan Tungku Keramik Dan Pemanas Nikelin. Universitas Negeri Yogyakarta.

Nugroho, S. et al. (2017) 'Redesain Kemasan Makanan Ringan Olahan pada UMKM Center Jawa Tengah dengan Metode Kansei Engineering', PERFORMA: Media Ilmiah Teknik Industri, 16(1). doi: 10.20961/performa.16.1.12758.

Puspitasari, D., Sugiharto and Anizar (2014) 'Perancangan Kompor Sekam Padi Pada Industri Pembuatan Tahu XYZ Menggunakan Metode Kansei Engineering’, Jurnal Teknik Industri USU, 5(1), pp. 13-17.

Rahmayani, N., Yuniar and Desrianty, A. (2015) 'Rancangan Kemasan Bedak Tabur (Loose Powder) Dengan Menggunakan Metode Kansei Engineering', Jurnal Online Institut Teknologi Nasional, 03(04), pp. 170-179.

Subiantoro, I. and Wiwi, U. (2015) 'Rancang Bangun Kompor Batubara Untuk Kebutuhan Industri Rumah Tangga', JRM, 02(03), pp. 64-67. doi: 10.1377/hlthaff.2013.0625.

Sugiyono (2017) Metode Penelitian Kuantitatif, Kualitatif, dan R\&D. Bandung: CV. Alfabeta.

Wahyuning, C. S., Desrianty, A. and Rahmawati, R. (2011) 'Studi Rancangan Konsep Produk Brassiere Melalui Pendekatan Nilai Emosi Dan Perasaan Menggunakan Kansei Engineering Method', Jurnal Itenas Rekarupa, 1(1), pp. $56-69$.

Wijana, M. and Nurchayati, N. (2013) 'Desain Tungku Briket Biomassa System Kontinyu Sebagai Teknologi Pemanfaatan Energi Alternatif Pengganti Bahan Bakar Terpakai Pada Oven Tembakau Di Masyarakat Pedesaan', Dinamika Teknik Mesin, 3(1), pp. 60-66. doi: 10.29303/d.v3i1.89. 